\title{
Evaluation of stress distribution in maxillary central incisor restored with different post materials: A three-dimensional finite element analysis based on micro-CT data
}

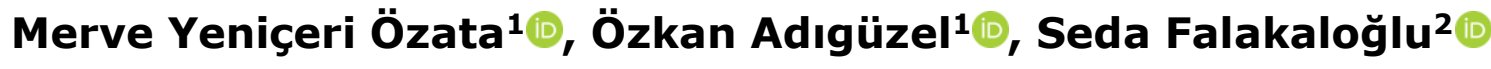 \\ ${ }^{1}$ Dicle University, Faculty of Dentistry, Department of Endodontics, Diyarbakır, Turkey \\ ${ }^{2}$ Afyonkarahisar Health Sciences University, Faculty of Dentistry, Department of Endodontics, Afyonkarahisar, Turkey
}

\section{Correspondence:}

Dr. Merve YENIÇERI ÖZATA Dicle University, Faculty of Dentistry, Department of Endodontics, Diyarbakır, Turkey. E-mail:

merveyeniceri05@hotmail.com

Received: 5 May 2021

Accepted: 23 September 2021

\section{Access Online}

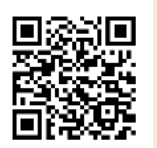

DOI:

10.5577/intdentres.2021.vol11.no3.3

\section{Abstract}

Aim: Post-core restorations have been developed to restore and re-functionalize endodontically treated teeth. Today, post-core materials used to show stress distribution similar to a solid tooth are still being researched. This study aimed to compare the von Mises stress ( $\sigma \mathrm{vm})$ distributions created by the Zirconium post (ZP), Titanium post (TP), and Glass Fiber post (GFP) materials in the permanent maxillary central incisor using finite element stress analysis (FEA).

Methodology: A permanent maxillary central incisor tooth scanned using microcomputed tomography $(\mu \mathrm{CT})$ was reconstructed, and a three-dimensional model was created. To these models, ZP, TP, and GFP were applied. Composite resin was modeled as the core structure and ceramic crown as the superstructure. Using FEA, $100 \mathrm{~N}$ static force was applied in three directions with vertical $\left(\mathrm{F} 1-0^{\circ}\right)$, oblique $\left(\mathrm{F} 2-45^{\circ}\right)$, and horizontal $\left(\mathrm{F} 3-90^{\circ}\right)$ angles to the models whose restoration was completed. As a result of the applied forces, the stresses on the dentine model $(\mathrm{Dm})$, post model $(\mathrm{Pm})$, and the cement model in between the dentine and the post $(\mathrm{Cm})$ were compared.

Results: The maximum von Mises stress ( $\sigma \mathrm{vm}$ max) distribution under F1 for Dm was: $\mathrm{ZP}=6,07888 \mathrm{MPa}$, TP $=6,35719 \mathrm{MPa}$ and GFP $=6,81946 \mathrm{MPa}$. The $\sigma \mathrm{vm} \max$ distribution under the force F2 for Dm was: $Z P=26,6542 \mathrm{MPa}, T P=27,3694 \mathrm{MPa}$, and GFP $=28,4495 \mathrm{MPa}$. The $\sigma \mathrm{vm}$ max distribution under the force F3 for Dm was: $\mathrm{ZP}=34,7371 \mathrm{MPa}, \mathrm{TP}=34,9828 \mathrm{MPa}$, and GFP $=35,287 \mathrm{MPa}$.

The ovm max distribution under the force F1 for Pm was: ZP $=17,0361 \mathrm{MPa}$, TP $=13,1567 \mathrm{MPa}$, and GFP $=7,85452 \mathrm{MPa}$. The $\sigma \mathrm{vm}$ max distribution under the force F2 for Pm was: ZP = 73,7999 MPa, TP $=52,0089 \mathrm{MPa}$, and GFP $=25,9903 \mathrm{MPa}$. The ovm max distribution under the force $\mathrm{F} 3$ for Pm was: $\mathrm{ZP}=78,8934 \mathrm{MPa}$, TP $=$ 55,0424 MPa, and GFP = 27, $1787 \mathrm{MPa}$.

The ovm max distribution under the force F1 for $\mathrm{Cm}$ was: ZP $=7,95074 \mathrm{MPa}$, TP $=6,66092 \mathrm{MPa}$, and GFP $=4,60832 \mathrm{MPa}$. The $\sigma \mathrm{vm}$ max distribution under the force F2 for $\mathrm{Cm}$ was: $\mathrm{ZP}=16,8296 \mathrm{MPa}$, TP $=16,8514 \mathrm{MPa}$, and GFP $=16,526 \mathrm{MPa}$. The ovm max distribution under the force $\mathrm{F} 3$ for $\mathrm{Cm}$ was: $\mathrm{ZP}=17$, $5577 \mathrm{MPa}$, TP = $16,891 \mathrm{MPa}$, and GFP = 16,5209 $\mathrm{MPa}$.

Conclusion: In all three forces, the highest ovm max was at ZP, and the least was at GFP. ZP and TP accumulated forces internally rather than transmitting them to the tooth tissue. GFP distributed the forces more homogeneously to the dentine.

Keywords: stress distribution, zirconium post, glass fiber post, titanium post, finite element analysis.

How to cite this article: Yeniçeri Özata M, Adıgüzel Ö, Falakaloğlu S. Evaluation of stress distribution in maxillary central incisor restored with different post materials: A three-dimensional finite element analysis based on micro-CT data. Int Dent Res 2021;11(3):149-57. https://doi.org/10.5577/intdentres.2021.vol11.no3.3 


\section{Introduction}

Post-core systems have been developed to preserve the integrity of the remaining dental tissue after endodontic treatment. The systems distribute functional loads throughout the dental tissue and ensure retention of the restoration. One of the disadvantages of this system is that it may cause root fractures (1). In post-core applications, because the variables that cause fracture are biomechanically essential, they have been the subject of research by endodontists and prosthodontists (2-4). Fracture resistance depends on the shape of the remaining cavity (5), the adhesive material (6), the restored tooth (7), and the post-core material $(2,8)$. However, as with other variables (9), ideal post-core material is essential (10).

Metal posts corrode, causing discoloration in teeth and periodontal tissues. In turn, this creates inhomogeneous stress points in the root. In recent years, the roots have been replaced by aesthetic posts reinforced with zirconium and fiber $(11,12)$.

Although ZPs are biocompatible and resistant to galvanic corrosion and providing sufficient light transmittance in the cervical root area is aesthetically advantageous, their high modulus of elasticity increases the risk of root fracture $(4,13)$.

In addition to the aesthetic advantages, fiber posts provide a fair distribution of stress to the restoration, thanks to their elasticity module close to dental tissue. Root fractures that may occur in fiber post systems are more likely to be seen in areas that will allow the restoration to be repeated (11).

Although TPs are metal materials, they have the lowest corrosion rate and good biological compatibility. The radiopacity of titanium alloys is close to guttapercha and canal sealers, making it difficult to detect on radiography. They have low fracture resistance, so they cannot be applied to very thin root canals (9).

FEA is a numerical engineering method used to analyze strain and stress occurring under force in complex structures (14). Because clinical variables are often not controlled in in vivo studies (1), it is impossible to place devices such as strain gauges on the inner wall of the root canal (15). Laboratory studies, FEA, or a combination are used to evaluate the mechanical behavior of post-core systems (16).

This study aimed to examine the stress distribution of GFP, TP, and ZP materials applied to the permanent maxillary central tooth model obtained using $\mu C T$ scanning in a three-dimensional (3D) virtual environment and under static occlusal forces in dentin, post, and cement. The null hypothesis of this study was that the stress distributions created by the three modeled post materials under occlusal forces would be similar across the dentin, post, and dentin-post interfaces.

\section{Materials and Methods}

The Local Ethics Committee of the Faculty of Dentistry at Dicle University, Diyarbakır, Turkey, approved this study (Decision no: 2017/28). One human maxillary permanent central incisor with a single root and a single canal without caries and restoration was used in this study.

A four-step method was followed to create the FEA model of the permanent maxillary central incisor (6).

1. The tooth was scanned with a high-resolution SkyScan $1172 \mu \mathrm{BT}$ (Bruker, Kontich, Belgium) at a voxel size of $13.68 \mu \mathrm{m}$. A total of 1,773 sections were obtained. Scanning was completed twice at $180^{\circ}$ with a rotation step of $0.9^{\circ}$. Digital Imaging and Communication in Medicine (DICOM) compliant images were saved in Tagged Image File Format (TIFF) format. Images were reconstructed in 76 seconds using NRecon (v.1.6.10.6 Skyscan, Kontich, Belgium) volumetric reconstruction software. Images were saved in Bitmap (BMP) format.

2. To create a geometric model of the jaw, the maxilla of a fully edentulous adult patient was scanned in cone-beam computed tomography (ILUMA, Orthocad, 3M Imtec, Oklahoma, USA). During scanning, 601 sections with $0.2 \mathrm{~mm}$ thickness were obtained in 40 seconds at $120 \mathrm{kV}$ and $3.8 \mathrm{~mA}$, and the sections were reconstructed. The sections were translated into a $3 \mathrm{D}$ model (3D) consisting of elements with uniform proportions using the "Complex Render" method in 3DDoctor (Able Software Corporation, MA, USA) software. The 3D model was transferred from 3D-Doctor software in stereolithography (STL) format. Cortical and cancellous bone harmony was achieved with the Boolean method in Rhinoceros 4.0 (McNeel North America, Seattle, WA, USA) software.

3. A $0.25 \mathrm{~mm}$ thick periodontal ligament (PDL) was modeled around the root using the Rhinoceros software. To provide apical sealing, the $4 \mathrm{~mm}$ Protaper F4 (Dentsply Maillefer, Ballaigues, Switzerland) guttapercha model was applied to the root canal system 1 $\mathrm{mm}$ shorter than the apical. The posts used in the study were modeled as $1.6 \mathrm{~mm}$ in diameter and $15.5 \mathrm{~mm}$ in length. The ferrule was not created, and the entire root was modeled as dentin, neglecting sealer thickness. The dual-cure resin cement (RelyX ARC, 3M ESPE, St Paul, USA) between the dentine-post and crown-core was modeled, with a cement thickness of $25 \mu \mathrm{m}$. The cement thickness was increased in areas where post adaptation was insufficient. All posts were designed in a structure with a parallel and conical end. A $1 \mathrm{~mm}$ thick $135^{\circ}$ chamfer design step was created on the core at the gingival level. The amount of occlusal reduction was $2 \mathrm{~mm}$, and the axial reduction amount was $1 \mathrm{~mm}$. The tooth form was prepared so that the axial wall angle was 6-8 ${ }^{\circ}$. The thickness of the IPS Empress II (Ivoclar Vivadent, Schaan, Liechtenstein) crown was $2 \mathrm{~mm}$ at the cutting edges and $1 \mathrm{~mm}$ in the other regions.

As a result, an incisor model adapted to the maxilla was obtained (Fig. 1). The models made in Rhinoceros were transferred to Fempro (Algor, Inc. Pittsburgh, PA, USA) software by preserving 3D coordinates. The models were converted into solid models in the form of bricks and tetrahedral elements. The solid and surrounding textures were modeled with a network consisting of 483,823 elements connected by 
90,544 nodes. The behavior of the models under stress was evaluated; the material values (Elasticity modulus and Poisson's ratio) describing the physical properties of each structure are shown in Table 1. All models were accepted as linear, homogeneous, and isotropic.

4. For stress analysis (using VRMesh Studio, VirtualGrid Inc, Bellevue, WA, USA, and Fempro analysis program), nine scenarios were created on three post models under the conditions of loading forces in three directions. A force of $100 \mathrm{~N}$ was applied to the model, representing the masticatory force, parallel to the long axis of the tooth $\left(\mathrm{F} 1-0^{\circ}\right)$, in the oblique direction $\left(\mathrm{F} 2-45^{\circ}\right)$ in the palatal region, and perpendicular to the long axis of the tooth $\left(\mathrm{F} 3-90^{\circ}\right)$ (Fig. 2).

Table 1. The physical properties of materials

\begin{tabular}{|c|c|c|c|}
\hline Material & E (Gpa) & V & References \\
\hline Cortical bone & 13.07 & 0.30 & (34) \\
\hline Trabecular bone & 1.37 & 0.30 & (34) \\
\hline Dentin & 18.6 & 0.31 & (34) \\
\hline PDL & 0.0689 & 0.45 & (34) \\
\hline Gutta-percha & 0.00069 & 0.45 & (34) \\
\hline Glass Fiber post (Snowlight, Carbotech, USA) & 49 & 0.28 & (8) \\
\hline Titanium post (Svenska, Dentorama, Sweden) & 103 & 0.33 & $\begin{array}{l}\text { Provided by } \\
\text { manufacturer }\end{array}$ \\
\hline $\begin{array}{c}\text { Zirconium post (Cosmopost, Ivoclar Vivadent, Schaan, } \\
\text { Liechtenstein) }\end{array}$ & 150 & 0.25 & (19) \\
\hline Composite resin core (Filtek Supreme XT, 3M ESPE, USA) & 12.7 & 0.35 & (37) \\
\hline Dual cure resin cement (Rely X ARC, 3M ESPE, USA) & 4.92 & 0.27 & (38) \\
\hline $\begin{array}{l}\text { IPS Empress II porcelain (Ivoclar Vivadent, Schaan, } \\
\text { Liechtenstein) }\end{array}$ & 67.2 & 0.30 & (39) \\
\hline
\end{tabular}

E: Elastic modulus V: Poisson's ratio

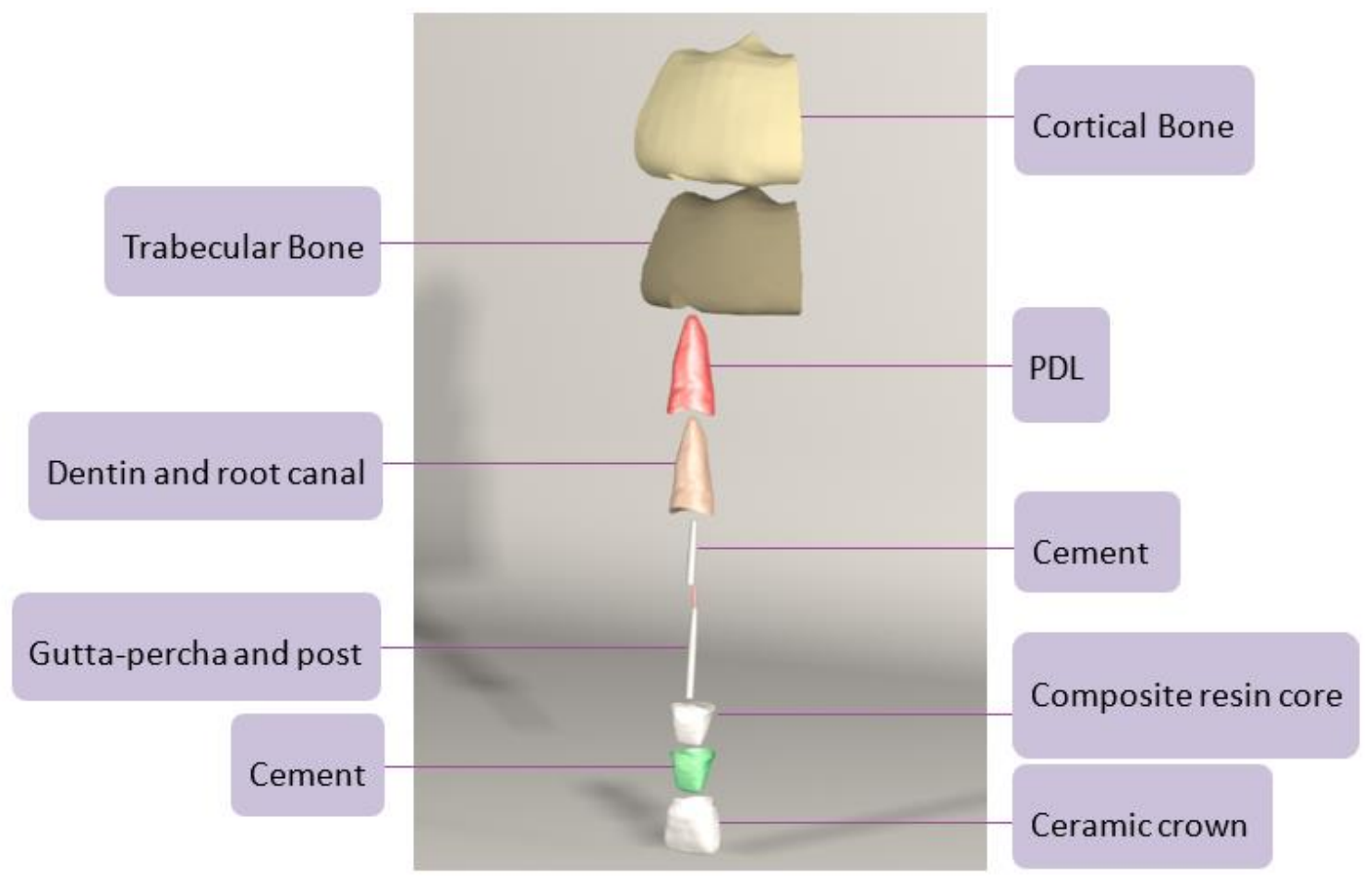

Figure 1. The layers that comprise the model 


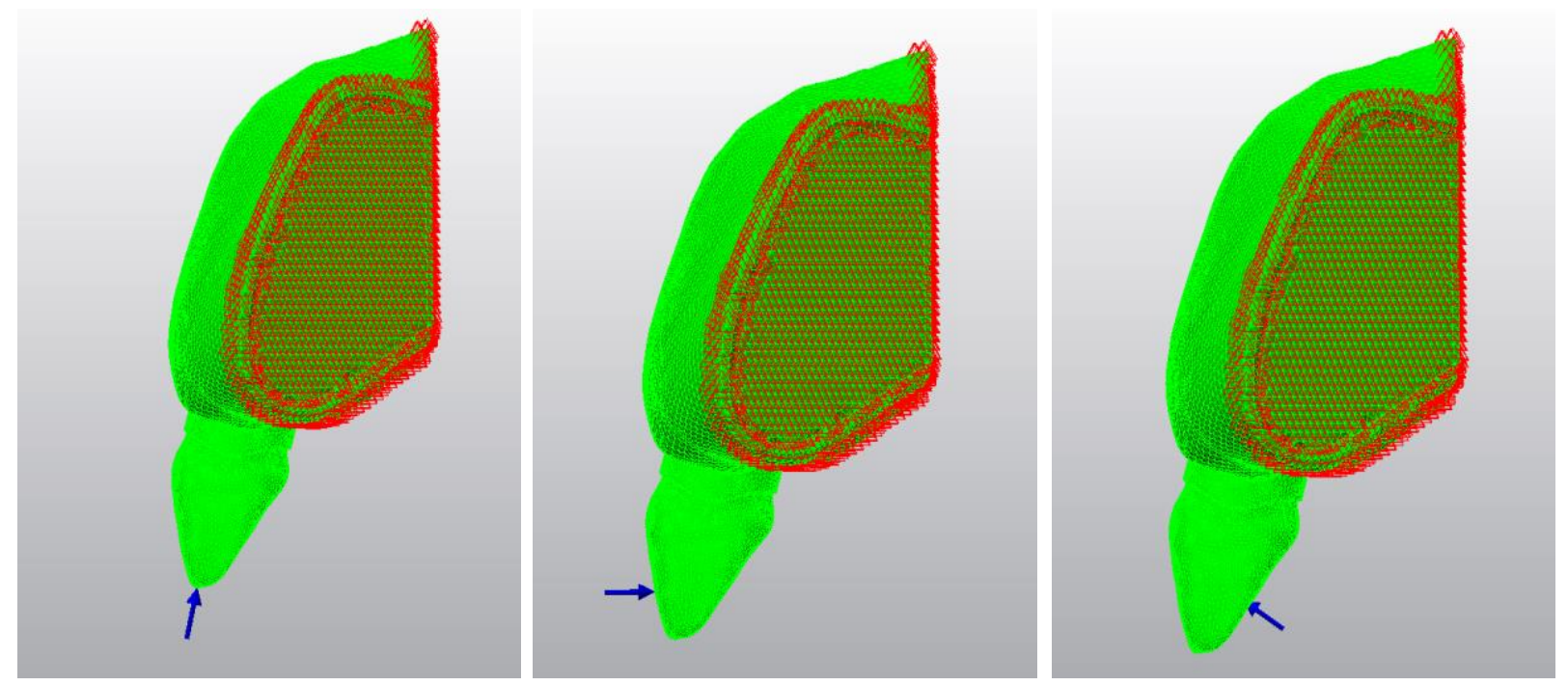

Figure 2. F1, F2, and F3 forces applied to models

\section{Results}

After the F1, F2, and F3 forces were applied in the created models, the minimum and maximum ovm distributions and quantities in $\mathrm{Dm}, \mathrm{Pm}$, and $\mathrm{Cm}$ were obtained (Table 2). It was expected that there would be an accumulation of stress in the area where the force was applied. The stress values obtained from the models resulting from the stress analysis were specified as maximum and minimum. Mathematical values were given in $\mathrm{MPa}$.

The stresses occurring in Dm under F1 force were: $\mathrm{ZP}=6.07888 \mathrm{MPa}, \mathrm{TP}=6.35719 \mathrm{MPa}$, and GFP $=6.81946$ $\mathrm{MPa}$. The stress was concentrated in the labial of the root and the cervical third; the stress value was the highest in the GFP applied Dm model (Fig. 3a). The stresses occurring in $\mathrm{Pm}$ under $\mathrm{F} 1$ stress were: $\mathrm{ZP}=$ $17.0361 \mathrm{MPa}, \mathrm{TP}=13.1567 \mathrm{MPa}$, and GFP $=7.85452$ $\mathrm{MPa}$. Stress accumulation was high in the part close to the coronal third in the GFP and TP, while more accumulated stress was observed in the middle third in ZP (Fig. 4a). The stress ranking in $\mathrm{Cm}$ under $\mathrm{F} 1$ force was: $\mathrm{ZP}=7.95074 \mathrm{MPa}$, TP $=6.66092 \mathrm{MPa}$, and GFP = 4.60832 MPa. Also, ovmmax was at the apical of the Cms.

The stresses occurring in Dm under F2 force were: $\mathrm{ZP}=26,6542 \mathrm{MPa}$, TP $=27,3694 \mathrm{MPa}$, and GFP = 28,4495 $\mathrm{MPa}$. The stress was concentrated in the root's labial, cervical, and middle third and decreased towards the apical region. Stress accumulation was highest in the GFP applied Dm model (Fig. 3b). The stresses occurring in $\mathrm{Pm}$ under $\mathrm{F} 2$ force were $\mathrm{ZP}=73.7999 \mathrm{MPa}$, TP = 52.0089 $\mathrm{MPa}$, and GFP $=25.9903 \mathrm{MPa}$; significant differences were observed. In addition, stress accumulation was concentrated in the middle and apical third of the post in all three post materials (Fig. $4 \mathrm{~b})$. The order of stresses in $\mathrm{Cm}$ under F2 force were: $\mathrm{ZP}=16.8296 \mathrm{MPa}, \mathrm{TP}=16.8514 \mathrm{MPa}$, and GFP $=16.526$ $\mathrm{MPa}$. In all $\mathrm{Cms}$, ovmmax was in the cervical third (Fig. 5b).

The stresses in $\mathrm{Dm}$ under $\mathrm{F} 3$ force were: $\mathrm{ZP}=$ 34.7371 MP, TP = 34.9828 MPa, and GFP = 35.287 MPa. The highest stress value was seen in the GFP applied Dm model. Stress accumulation was concentrated in the labial of the root, primarily in the cervical and middle third in all models (Fig. 3c). The order of stress values in Pm was similar to the F1 and F2 forces: $\mathrm{ZP}=$ $78.8934 \mathrm{MPa}$, TP $=55.0424 \mathrm{MPa}$, and GFP $=27.1787$ $\mathrm{MPa}$. Stress was concentrated in the middle and apical third in all Pms (Fig. 4C). The order of stresses in $\mathrm{Cm}$ was: $\mathrm{ZP}=17.5577 \mathrm{MPa}$, TP $=16.891 \mathrm{MPa}$, and GFP $=$ 16.5209 $\mathrm{MPa}$. In all Cms, ovmmax was in the cervical third (Fig. 5c).

The ovmmax values formed by F1, F2, and F3 forces on dentine, post, and cement were compared for all post materials. The most stressful force was F3, then F2, and the least stressful F1 force. The modulus of elasticity (rigidity) of the modeled post material was inversely proportional to the amount of stress accumulated in the dentin. 
Table 2. ovm stress distribution values in $\mathrm{Dm}$, $\mathrm{Pm}$, and $\mathrm{Cm}(\mathrm{MPa})$

\begin{tabular}{|c|c|c|c|c|}
\hline & & Dentin Model (Dm) & Post Model (Pm) & Cement model $(\mathrm{Cm})$ \\
\hline Post type & Force direction & $\operatorname{Max} / \operatorname{Min}$ & $\operatorname{Max} / \operatorname{Min}$ & $\operatorname{Max} / \operatorname{Min}$ \\
\hline \multirow{3}{*}{$\begin{array}{l}\text { Glass fiber } \\
\text { post (GFP) }\end{array}$} & F1 & $6,81946 / 0,526559$ & $7,85452 / 1,56067$ & $4,60832 / 0,223494$ \\
\hline & $F 2$ & 28,4495 / 1,73425 & $25,9903 / 1,7392$ & $16,526 / 0,570489$ \\
\hline & F3 & $35,287 / 2,37816$ & 27,1787 / 1,10907 & $16,5209 / 0,817684$ \\
\hline \multirow{3}{*}{$\begin{array}{l}\text { Titanium } \\
\text { post (TP) }\end{array}$} & F1 & 6,35719 / 0,46457 & $13,1567 / 2,60662$ & $6,66092 / 0,164017$ \\
\hline & F2 & 27,3694 / 1,70053 & $52,0089 / 2,68703$ & $16,8514 / 0,509749$ \\
\hline & F3 & 34,9828 / 2,28987 & $55,0424 / 2,13056$ & $16,891 / 0,787838$ \\
\hline \multirow{3}{*}{$\begin{array}{l}\text { Zirconium } \\
\text { post (ZP) }\end{array}$} & $\mathrm{F} 1$ & $6,07888 / 0,421797$ & $17,0361 / 3,0328$ & 7,95074 / 0,188196 \\
\hline & $F 2$ & $26,6542 / 1,75504$ & 73,7999 / 3,15051 & $16,8296 / 0,683811$ \\
\hline & F3 & $34,7371 / 2,2016$ & 78,8934 / 2,49809 & 17, $5577 / 0,729908$ \\
\hline
\end{tabular}

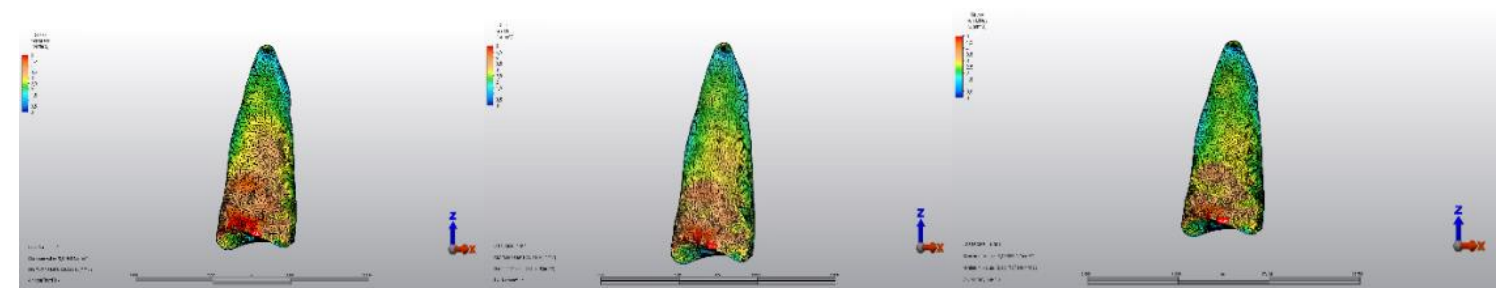

Figure 3a. Stress distribution in Dms under F1 force (in order of GFP, TP, and ZP)

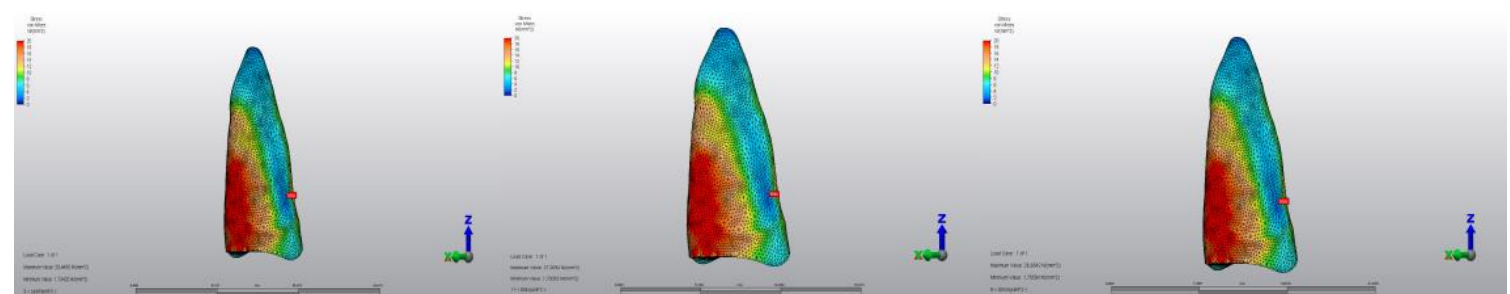

Figure 3b: Stress distribution in Dms under F2 force (in order of GFP, TP, and ZP)

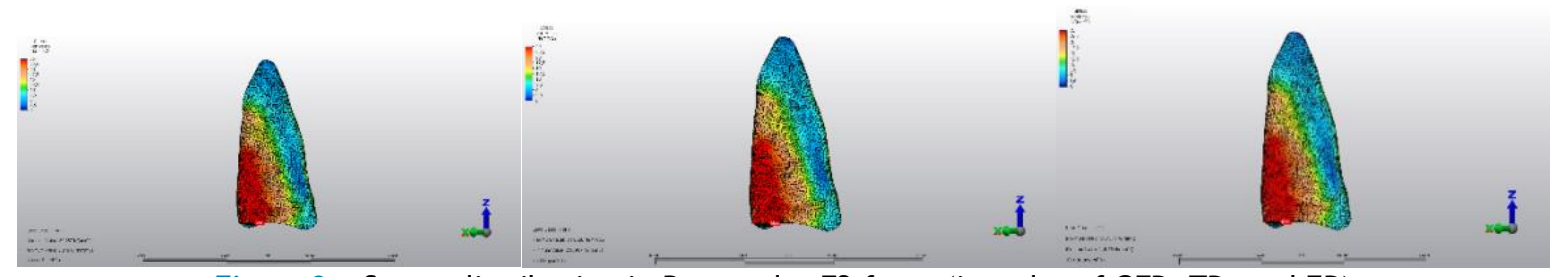

Figure 3c: Stress distribution in Dms under F3 force (in order of GFP, TP, and ZP) 


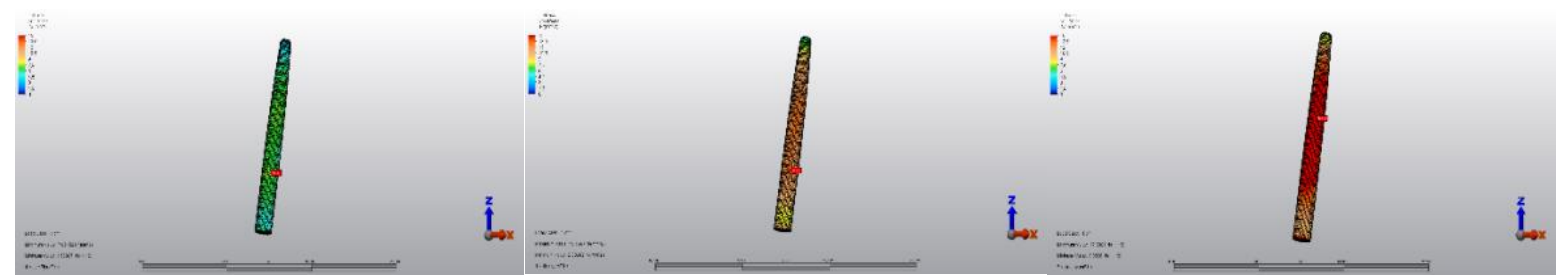

Figure 4a: Stress distribution in Pms under F1 force (in order of GFP, TP, and ZP)

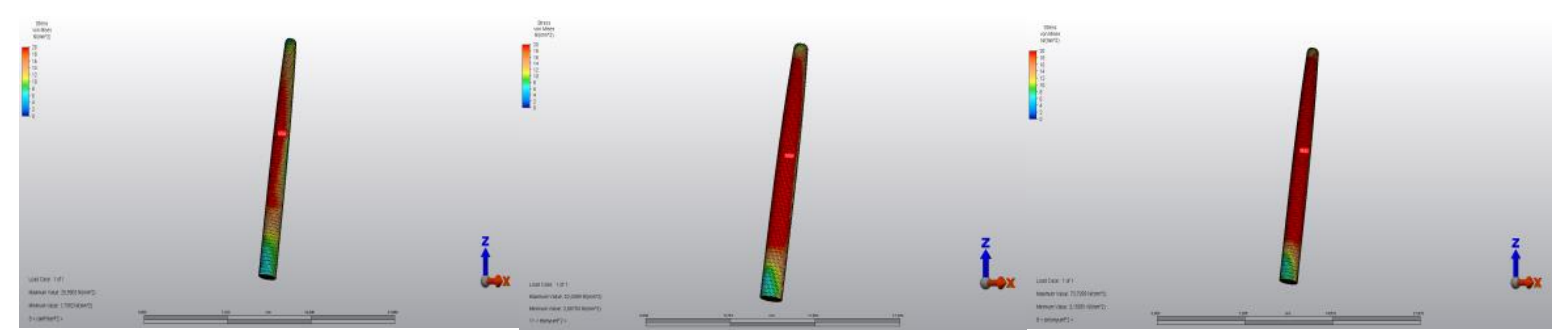

Figure 4b: Stress distribution in Pms under F2 force (in order of GFP, TP, and ZP)

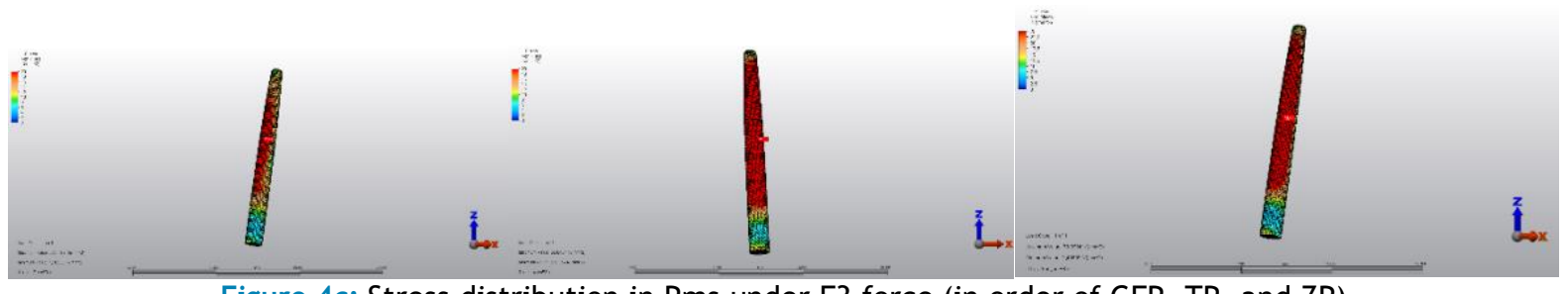

Figure 4c: Stress distribution in Pms under F3 force (in order of GFP, TP, and ZP)

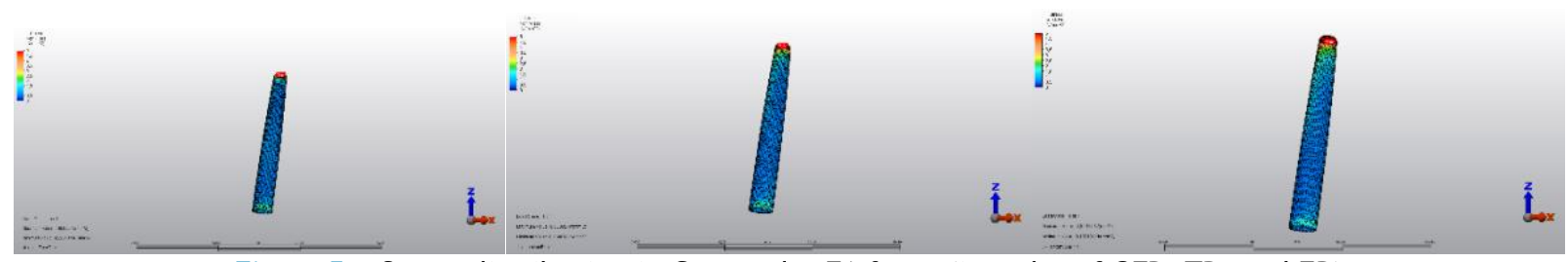

Figure 5a: Stress distribution in Cms under F1 force (in order of GFP, TP, and ZP)

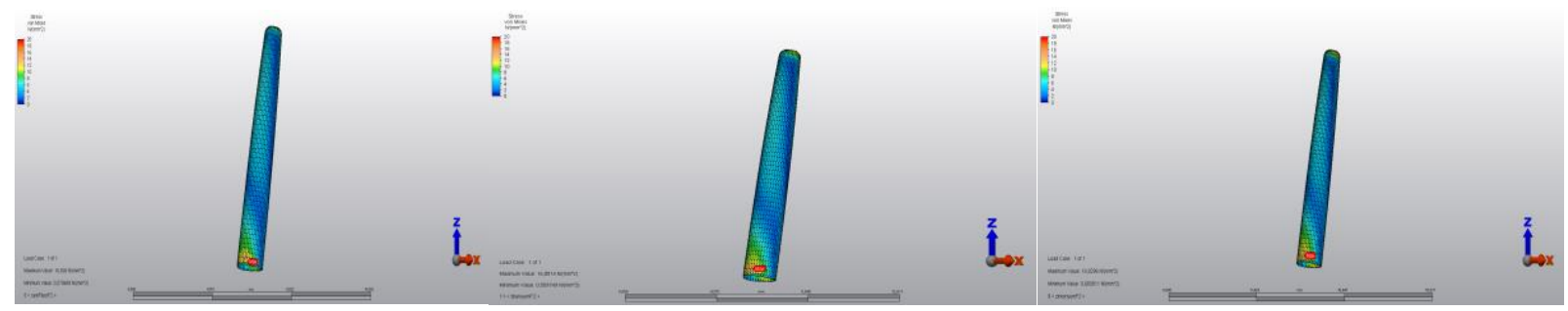

Figure 5b: Stress distribution in Cms under F2 force (in order of GFP, TP, and ZP)

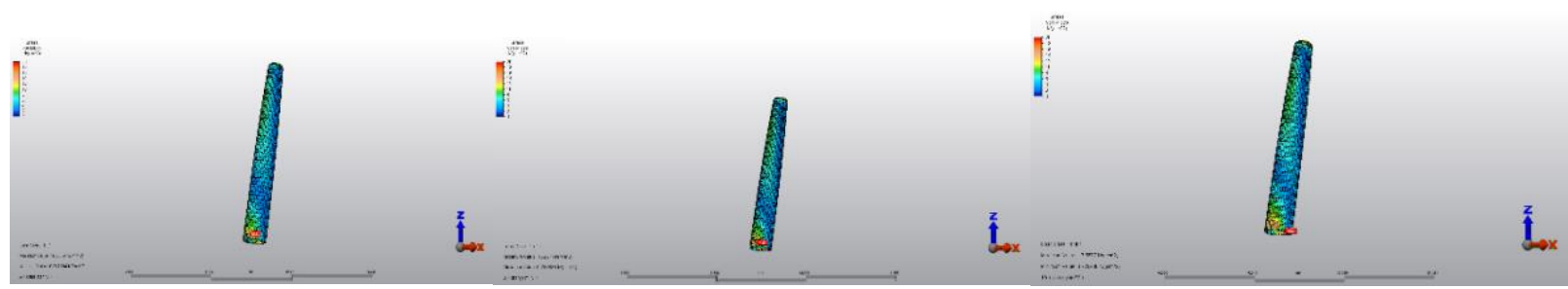

Figure 5c: Stress distribution in Cms under F3 force (in order of GFP, TP, and ZP) 


\section{Discussion}

Post-core restorations applied to teeth with root canal treatment have two indications: strengthening the damaged tooth tissue and providing resistance to the repair (17). Many different post-core materials have been used from past to present. Rigid post-core systems cause destructive stresses in dental tissues under functional forces (18). Therefore, there is a tendency to use materials whose physical properties are closer to dental tissues in post-core construction (2, $4,19)$.

TP from metal alloy posts, GFP from fiberreinforced posts, and ZP from ceramic posts were preferred to shed light on post preferences in clinical use. The goal was to compare three post systems according to the material from which they were made.

The FEA method utilized mathematical modeling software. It was made by numerically analyzing the deformation that the model created from the elements would exhibit under loads (20). In in vitro studies, available variables are not fully controlled, and results may differ. The tooth, post, and force modeling used in this study were accomplished in the FEA environment.

While, in some studies, the 3D geometric tooth model is created in a virtual environment using the FEA method (1-3), there are many FEA studies based on $\mu \mathrm{BT}$ with the advancement of technology (21-24). In finite element models made using the $\mu \mathrm{BT}$ technique, both bone and tooth tissue (enamel, dentin, and pulp) can be distinguished precisely (25). In this study, to standardize the 3D real tooth geometry for all scenarios, $\mu \mathrm{CT}$ images of an extracted human maxillary central tooth was used.

In FEA studies, the number of elements and nodes is essential for analysis. Node and element numbers determine the sensitivity of the investigation. As the number of components increases, realistic results can be obtained (26). In the models used for our analysis, the number of elements and nodes were 483,823 and 90,544 . Belli et al. used 34,515 elements and 13,300 nodes. Sorrentino et al. used 13,272 elements and 15,152 nodes. Nokar et al. used 4,300 elements and 6,000 nodes. Spazzin et al. used 109,141 elements and 133,681 nodes $(3,4,27,28)$. In this study, we believed that by increasing the number of elements and nodes, realistic results were obtained.

Smith et al. concluded that the most suitable post design in terms of biomechanics is the parallel-conical design (29). In our study, posts were modeled to be parallel-conical. The periodontal ligament, cortical bone, and cancellous bone layers were also included. Because the modulus of elasticity was accepted as equivalent to dentin, the cementum layer was accepted as part of the dentine (30).

Kohal et al. observed that one-third of the maximum bite force of $300 \mathrm{~N}$ was the normal chewing force (31). Helkimo et al. stated that the forces generated during occlusion in the anterior region ranged from 100 to $200 \mathrm{~N}$ (32). In some of the reviewed 3D FEA studies, the force magnitude was chosen as 100 $\mathrm{N}$. Therefore, F1, F2, and F3 in our study were International Dental Research $\odot 2021$ determined to be $100 \mathrm{~N}$ for comparison. In the FEA study by Garhnayak et al., the resulting stress increased as the direction of the forces on the tooth changed from vertical to horizontal (33). In the vertical force, a more homogeneous stress distribution occurs because all the periodontal fibers are in function. As a result of oblique forces, the rotation center was formed along the long axis of the tooth, so the stress distribution was not homogeneous (34). In the stress values created by the forces applied to our models, the highest values were seen in the horizontal forces (F3), followed by the chewing force (F2) and the vertical force $(F 1)$. There were no significant differences between stress concentrations in vertical forces and homogeneously distributed stresses.

In their FEA study, Adanır et al. used stainless steel, cast gold, glass fiber, carbon fiber, and titanium posts by applying $200 \mathrm{~N}$ static forces at $0^{\circ}$ and $45^{\circ}$ angles. They reported that glass fiber and carbon fiber posts showed balanced stress distribution under functional forces (35). An FEA study found that stainless steel, glass fiber, and biological dentin posts did not cause excessive stress accumulation on the tooth and post surface. The post material resisted stress by forming a monoblock structure with the dental tissue (8). Our study observed that GFP showed an acceptable stress distribution in terms of biomechanics for all three forces, consistent with these studies. It has been observed that the stress occurring at the dentin-post interface is less in GFP applied models. We attribute this result to the high flexibility of glass fiber post material and its ability to distribute stress to dentin tissues without accumulating stress in its internal structure.

Asmussen et al. examined two Zirconium posts (Biopost and Cerapost), a titanium post (PCR), and a carbon fiber post (Composipost) for their hardness and elastic limit properties. They were subjected to force loading at an angle of $45^{\circ}$ by cementing the posts into a block. They observed that ZPs were extremely hard and did not exhibit plastic properties. TP's were as durable as ZPs. However, they stated that their rigidity was less than the ZP's (36). In our study, the lower stress level in the titanium post compared to the zirconium post coincided with this study. In addition, the inability of ZP to transmit stress to the dentin and accumulating along the post surface may be a possible cause of fracture.

Nokar et al. examined the stress distribution created by different post and core materials only in dentin by creating 12 scenarios. They were examined under $100 \mathrm{~N}$ force at an angle of $45^{\circ}$. The authors reported higher stress levels in the middle and cervical third of the root in fiber-reinforced posts (27). In our models of F2 chewing force, the highest stress values were observed in the Dm, where GFP was applied. Further, in the GFP material, a high-stress level was observed in the cervical third of the root, also in accordance with this study. This finding suggests that fractures in teeth with GFP applied in clinical use may be more repairable in the cervical third of the root.

The FEA method is a fast and successful method used to evaluate stress distribution in post-core 
materials. However, the limitations of this method are that the tooth and periodontium, which are anisotropic, are accepted as isotropic structures in the models. The elastic modulus of dental hard tissues is not standard in each tooth.

\section{Conclusions}

Many variables play a role in the clinical success of post-core restorations. Some of those variables are ignored in FEA studies. In the stress analysis for all scenarios, GFP, which has a low elasticity modulus close to dentine, transmits stress to surrounding tissues homogeneously. At the same time, rigid TP and ZP materials responds to the stress within their structure. Given all of its limitations, and based on the results of our study, we believe that GFP restorations with an elasticity module close to dentin can eliminate the destructive stresses that may occur in endodontically treated teeth by distributing stresses to surrounding tissues.

Ethical Approval: Ethics Committee of the Faculty of Dentistry at Dicle University, Diyarbakır, Turkey, approved this study (Decision no: 2017/28).

Peer-review: Externally peer-reviewed.

Author Contributions: Conception - M.Y.Ö.; Design - Ö.A., M.Y.Ö.; Supervision - Ö.A.; Materials - M.Y.Ö., Ö.A.; Data Collection and/or Processing - M.Y.Ö., Ö.A.; Analysis and/or Interpretation - M.Y.Ö., S.F.; Literature Review -M.Y.Ö., S.F.; Writer -M.Y.Ö.; Critical Review - M.Y.Ö., Ö.A.

Conflict of Interest: No conflict of interest was declared by the authors.

Financial Disclosure: This research has been supported by Dicle University, Scientific Research Project Coordination Unit. Project Number: Diș.18.002.

\section{References}

1. Asmussen E, Peutzfeldt A, Sahafi A. Finite element analysis of stresses in endodontically treated, dowel-restored teeth. J Prosthet Dent 2005; 94(4): 321-9. (Crossref)

2. Madfa A, Kadir MA, Kashani J, Saidin S, Sulaiman E, Marhazlinda $J$, et al. Stress distributions in maxillary central incisors restored with various types of post materials and designs. Med Engin Physics 2014; 36(7): 962-7. (Crossref)

3. Sorrentino R, Aversa R, Ferro V, Auriemma T, Zarone F, Ferrari $M$, et al. Three-dimensional finite element analysis of strain and stress distributions in endodontically treated maxillary central incisors restored with diferent post, core and crown materials. Dent Mater 2007; 23(8): 983-93. (Crossref)

4. Belli S, Çelik K, Akbulut MB, Güneșer MB, Eraslan $O$, Eskitaçcioğlu G. Are dentin posts biomechanically intensive?: A laboratory and FEA study. J Adhesion Sci Technol 2014; 28(24): 2365-77. (Crossref)

5. Çobankara FK, Ünlü N, Çetin AR, Özkan HB. The effect of different restoration techniques on the fracture resistance of endodontically-treated molars. Oper Dent 2008; 33(5): 526-33.
(Crossref)

6. Ausiello P, Davidson C, Cascone P, DeGee A, Rengo S. Debonding of adhesively restored deep Class II MOD restorations after functional loading. Am J Dent 1999; 12(2): 84-8.

7. Wendt Jr S, Harris B, Hunt T. Resistance to cusp fracture in endodontically treated teeth. Dent Mater 1987; 3(5): 232-5. (Crossref)

8. Falakaloğlu S, Adıgüzel Ö, Özdemir G. Root canal reconstruction using biological dentin posts: A 3D finite element analysis. J Dent Res Dent Clin Dent Prospects 2019; 13(4) :274-80. (Crossref)

9. Schwartz RS, Robbins JW. Post placement and restoration of endodontically treated teeth: a literature review. J Endod 2004; 30(5): 289-301. (Crossref)

10. Faria ACL, Rodrigues RCS, de Almeida Antunes RP, de Mattos MdGC, Ribeiro RF. Endodontically treated teeth: characteristics and considerations to restore them. J Prosthodont Res. 2011; 55(2): 69-74. (Crossref)

11. Akkayan B, Gülmez T. Resistance to fracture of endodontically treated teeth restored with different post systems. J Prosthet Dent 2002; 87(4): 431-7. (Crossref)

12. Hochman N, Zalkind $M$. New all-ceramic indirect post-and-core system. J Prosthet Dent 1999; 81(5): 625-9. (Crossref)

13. Pest LB, Cavalli G, Bertani P, Gagliani M. Adhesive postendodontic restorations with fiber posts: push-out tests and SEM observations. Dent Mater 2002; 18(8): 596-602. (Crossref)

14. Craig RG, Hanks CT, Kohn DH et al. Mechanical properties. In: Craig RG Restorative dental materials. 9th ed. St. Louis: MosbyYear Book Inc; 1993. p. 54-105.

15. Dang DA, Walton RE. Vertical root fracture and root distortion: effect of spreader design. J Endod 1989; 15(7): 294-301. (Crossref)

16. Al-Omiri MK, Mahmoud AA, Rayyan MR, Abu-Hammad O. Fracture resistance of teeth restored with post-retained restorations: an overview. J Endod 2010; 36(9): 1439-49. (Crossref)

17. Sorensen JA, Martinoff JT. Clinically significant factors in dowel design. J Prosthet Dent 1984; 52(1): 28-35. (Crossref)

18. Torbjörner A, Karlsson S, Syverud M, Hensten-Pettersen A. Carbon fiber reinforced root canal posts mechanical and cytotoxic properties. Eur J Oral Sci 1996; 104(5-6): 605-11. (Crossref)

19. Shetty PP, Meshramkar R, Patil KN, Nadiger RK. A finite element analysis for a comparative evaluation of stress with two commonly used esthetic posts. Eur J Dent. 2013; 7(4): 419-22. (Crossref)

20. Van Noort R, Cardew G, Howard I, Noroozi S. The effect of local interfacial geometry on the measurement of the tensile bond strength to dentin. J Dent Res 1991; 70(5): 889-93. (Crossref)

21. Huang $Z$, Chen Z. Three-dimensional finite element modeling of a maxillary premolar tooth based on the micro-CT scanning: a detailed description. J Huazhong Univ Sci Technol Med Sci 2013; 33(5): 775-9. (Crossref)

22. Lazari PC, Oliveira RCN, Anchieta RB, Almeida EO, Freitas Junior AC, Kina $S$, et al. Stress distribution on dentin-cementpost interface varying root canal and glass fiber post diameters. A three-dimensional finite element analysis based on micro-CT data. J Appl Oral Sci 2013; 21(6): 511-7. (Crossref)

23. Diana HH, Oliveira JS, Ferro MCL, Silva-Sousa YTC, Gomes ÉA. Stress distribution in roots restored with fiber posts and an experimental dentin post: 3D-FEA. Braz Dent J 2016; 27(2): 223-7. (Crossref)

24. Watanabe MU, Anchieta RB, Rocha EP, Kina S, Almeida EO, Freitas-Junior AC, et al. Influence of crown ferrule heights and dowel material selection on the mechanical behavior of rootfilled teeth: a finite element analysis. J Prosthodont 2012; 21(4): 304-11. (Crossref)

25. Wain MV, Xue J. State of the art of Micro-CT applications in dental research. Int J Oral Sci 2009; 1(4): 177-88. (Crossref) 
26. Owen DRJ, Hinton E. A simple guide to finite elements. Swansea, UK: Pineridge Press; 1983. p. 136.

27. Nokar S, Bahrami M, Mostafavi AS. Comparative evaluation of the effect of different post and core materials on stress distribution in radicular dentin by three-dimensional finite element analysis. J Dent Tehran 2018;15(2):69-78.

28. Spazzin AO, Galafassi D, de Meira-Júnior A, Braz R, Garbin C. Influence of post and resin cement on stress distribution of maxillary central incisors restored with direct resin composite. Oper Dent 2009; 34(2): 223-9. (Crossref)

29. Smith CT, Schuman NJ, Wasson W. Biomechanical criteria for evaluating prefabricated post-and-core systems: A guide for the restorative dentist. Quintessence Int 1998; 29(5): 305-12.

30. Ho MH, Lee SY, Chen HH, Lee MC. Three-dimensional finite element analysis of the effects of posts on stress distribution in dentin. J Prosthet Dent 1994; 72(4): 367-72. (Crossref)

31. Kohal RJ, Papavasiliou G, Kamposiora P, Tripodakis A, Strub JR. Three-dimensional computerized stress analysis of commercially pure titanium and yttrium-partially stabilized zirconia implants. Int J Prosthodont 2002; 15(2): 189-94.

32. Helkimo E, Carlsson GE, Carmeli Y. Bite force in patients with functional disturbances of the masticatory system. J Oral Rehab 1975; 2(4): 397-406. (Crossref)

33. Garhnayak L, Parkash H, Sehgal D, Jain V, Garhnayak M. A
Comparative study of the stress distribution in different endodontic post-retained teeth with and without ferrule design-a finite element analysis. ISRN Dent 2011;2011. (Crossref)

34. Ko CC, Chu CS, Chung KH, Lee MC. Effects of posts on dentin stress distribution in pulpless teeth. J Prosthet Dent 1992; 68(3): 421-7. (Crossref)

35. Adanır N, Belli S. Stress analysis of a maxillary central incisor restored with different posts. Eur J Dent 2007;1(2):67-71. (Crossref)

36. Asmussen E, Peutzfeldt A, Heitmann T. Stiffness, elastic limit, and strength of newer types of endodontic posts. J Dent 1999; 27(4): 275-8. (Crossref)

37. Moszner N, Salz U. New developments of polymeric dental composites. Prog Polym Sci 2001; 26(4): 535-76. (Crossref)

38. De Jager N, Pallav P, Feilzer AJ. The apparent increase of the Young's modulus in thin cement layers Dent Mater 2004; 20(5): 457-62. (Crossref)

39. Imanishi A, Nakamura T, Ohyama T, Nakamura T. 3-D Finite element analysis of all-ceramic posterior crowns. J Oral Rehab 2003; 30(8): 818-22. (Crossref) 